\title{
Techno-Economic Investigation of a Thermal Cure Center Excess Heat Recovery System for Producing Hot Water for a Hotel in Antsirabe Madagascar
}

\author{
Hery Tiana Rakotondramiarana*, Mamy Harimisa Radanielina and Andriamaholisoa Yvan \\ Ramananjatovo
}

Institute for the Management of Energy (IME), University of Antananarivo, Po Box 566, Antananarivo 101, Madagascar

\begin{abstract}
Energy saving is a significant feature to take in account in the choice of renewable energy technologies to use. This paper techno-economically investigates an excess heat recovery system that is proposed to be installed in a thermal cure center geothermal source for producing domestic hot water to be conveyed through piping to a nearby three star hotel located in Antsirabe Madagascar. For that purpose, the hotel hot water needs were determined by using an available online free code, called Solo, and the effectiveness-NTU method was used to size the plate heat exchanger to be used to recover the geothermal heat. The proposed hybrid geothermal solution performance was compared with that of hybrid solar energy water-heaters in terms of electricity consumption related to water temperature adjustment. It follows from comparison results that the proposed hybrid geothermal solution is more profitable and allows about 73.2 (\%) of electric energy saving while it is $54.9(\%)$ for hybrid solar option. Besides, economic evaluation confirmed that the geothermal installation allows a shorter return on investment more favorably.
\end{abstract}

Keywords: Heat recovery system, geothermal energy, heat exchanger, energy savings, domestic hot water production.

\section{INTRODUCTION}

Developing countries energy sector is essential to development process when energy demand grew by around 45 (\%) from 2000 to 2012 especially in subSaharan Africa countries [1] despite the fact that these countries have untapped renewable and green energy resources.

Though recent oil exploration in Madagascar has showed encouraging results, imported oil price has presently a significant negative impact on the stability of the local currency value, and resultantly on the country's economic development. In addition, more than half amount of its electricity is produced by conventional diesel thermal power plants [2], and many regions of the country are still suffering from power shortage during a couple of hours a day, due to insufficiency of power generation devoted oil whose amount is bounded by the electricity cost that is applied by the only subsidized public-managed power and water provider company (JIRAMA standing for Jiro sy Rano Malagasy) and that the average of population are able to afford presumably.

Generally, power availability is one of the main criteria to attract foreign investors in every sector of

*Address correspondence to this author at the Institute for the Management of Energy (IME), University of Antananarivo, Po Box 566, Antananarivo 101, Madagascar; Tel: 02613204987 12; Fax: 02612022279 26;

E-mail: rktmiarana@yahoo.fr

E-ISSN: 1929-6002/15 production. In particular, tourism is among the prominent sources of foreign currencies of this biodiversity rich and globally fourth largest island. As local hotels must meet international hostelry standards to improve their own performance, availability of domestic hot water is imperative for any hotel situated in temperate sub-climate areas like Antsirabe.

While enhancing the use of renewable energy technologies (RETs) obviously presenting good opportunities for the country's economic perspective; in addition to the implementation of the Malagasy government program on RETs development, every individual power user should use every effort to save energy, on the first hand, and to favor RETs on the other hand. An appropriate choice should though be done on the type of RETs to use for that purpose.

Geothermal energy is one of the green alternative resources to fossil fuels to reduce the depletion of available natural energy resources. To carry out the conversion of geothermal energy, it is necessary to previously extract geothermal water from a certain depth which may vary between shallow depth and very deep one. Typically, heat exchangers are used to utilize the heat from the pumped hot water. Lund et al. [3] have synthesized the geothermal energy applications for direct output using comparing data from several countries in the world.

Recent investigations tended to assess domestic hot water and energy production by using geothermal

(c) 2015 Lifescience Global 
resource with new generation system [4]. Li et al. [5] showed the improvement of geothermal system efficiency by substituting oil boilers with geothermal water. Besides, an assessment of hot water production in heating plant in Belgrade (Serbia) was presented by Jovanovic et al. [6]. They studied the importance of multi-criteria analysis to evaluate the sustainability of combined systems for obtaining thermal energy and hot water.

In Madagascar, there are approximately 175 thermal springs listed with temperatures over $25\left({ }^{\circ} \mathrm{C}\right)$ [7]. A certain number of establishments exploit some of these resources but the thermal cure of Antsirabe stands out as being under the tutelage of the Malagasy public Ministry of Health and being renowned for the therapeutic quality of the water. This thermal cure center draws its mineral water from a shallow groundwater and exploits a low geothermal energy. It turns out that its functioning occasions some heat excess that is unreasonably wasted and the objective of the present paper is to investigate if the heat recovery of such heat excess for producing domestic hot water would be more interesting for a nearby three stars hotel, called Hotel des Thermes, with regard to installing solar water-heaters (SWHs) for its hot water needs. In any case, this hotel uses a supplemental electrical heat source to better adjust water temperature to standard value of sanitary hot water to provide to its customers.

\section{DESCRIPTION}

Antsirabe is a city of the central highlands of Madagascar, is situated in $169(\mathrm{~km})$ in the South of Antananarivo (the capital city of Madagascar), peaks in $1500(\mathrm{~m})$ of height, and is well known for its numerous thermal springs. Literally, the name of the city means "a place where there is a lot of salt", in reference to the presence of minerals in waters of thermal springs.

Both establishments considered in the present study, namely: the thermal cure center and the "Hôtel des Thermes" are a part of the oldest establishments which still make the reputation of the city.

\subsection{Description of the Thermal Cure Center of Antsirabe}

This health resort consists of three buildings that can be described according to the age of construction as follow: Building $A$, Building $B$ and an Administration Building.
Built by 1925 , extending over $1,720\left(\mathrm{~m}^{2}\right)$, Building A is still in good condition and consists of 14 bathing huts among which 6 ordinary baths (for the public) and 8 medical baths for the persons having hydrotherapy, using directly the mineral water and the city water mixed directly in bathtubs. There are also nine rooms of treatment and extending bathing huts.

Built by 1945 , Building B covers an area of $740\left(\mathrm{~m}^{2}\right)$ and is presently unused because of the building dilapidation and the lack of operating staff, while it consists of 12 ordinary bathing huts and 2 locker rooms.

Built by 1970, Administration Building is located in the north of the center and consists of 5 checkup rooms, 4 administrative offices, 1 room of reserve stock, 1 pharmaceutical room, 2 reeducation rooms, 1 lingerie, 1 garage, 1 hall including a ticket office and a reception counter, 1 maintenance room, constituted by 2 pools for reeducation, and a unit of cure containing 10 rooms of hosting of the persons having hydrotherapy, an administrative housing, and rooms of preventive care and well-being. These facilities are spread over an area of $4,190\left(\mathrm{~m}^{2}\right)$.

\subsubsection{Geothermal Drilling}

The wells of the thermal cure center are drilled inside its enclosure. The Building $A$ is fed by a well that is hereafter named $\mathrm{R} 1$, whereas the Administration Building including swimming pools is supplied by a well that is in the following named R2. While having hard water proof, wells $\mathrm{R} 1$ and $\mathrm{R} 2$ are in that order characterized by nominal pipe diameters of $80(\mathrm{~cm})$ and $100(\mathrm{~cm})$, and the depths of these wells are respectively about $28(\mathrm{~m})$ and $32(\mathrm{~m})$ with temperatures of $47\left({ }^{\circ} \mathrm{C}\right)$ and $52\left({ }^{\circ} \mathrm{C}\right)$.

\subsubsection{Description of Thermal Center Working}

As shown in Figure 1, the well R1 feeds baths tub, pressurized showers and massage room. The collected hot water is sent to the distributing network and stocked in an insulated tank having a capacity of 10 $\left(\mathrm{m}^{3}\right)$. Hence, the hot water is supplied to two other insulated tanks such that the first with a capacity of 10 $\left(\mathrm{m}^{3}\right)$ feeds thermal baths and the second one of 15 $\left(\mathrm{m}^{3}\right)$ capacity supplies the pressurized showers and the massage room. These tanks are insulated to limit the heat losses and to keep up the temperature of geothermal water.

Figure 2 illustrates the well R2 functioning. The hot water directly feeds the swimming pool, the Jacuzzi and the wellness area. 


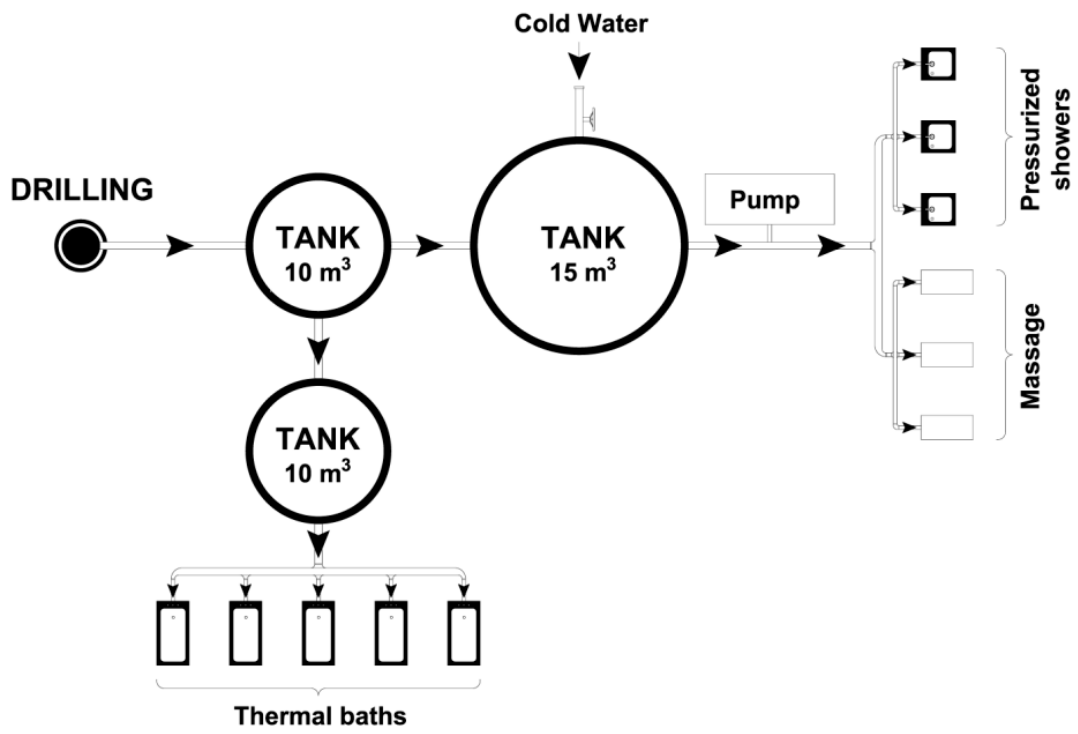

Figure 1: Simplified sketch of the system supplied by the well R1.

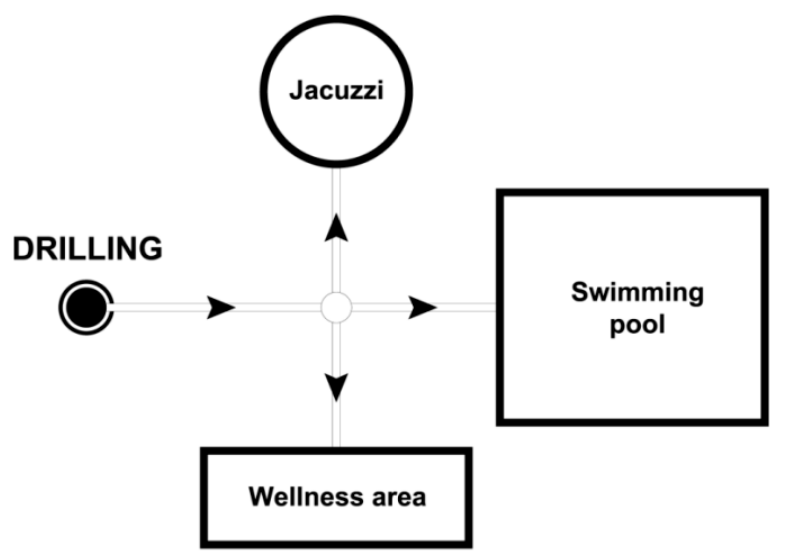

Figure 2: Simplified sketch of the system supplied by the well $\mathrm{R} 2$.

It is worthwhile noting that the center is closed for two weeks a year due to annual technical maintenance. Henceforth, the usage time of the center is fixed to 350 days.

\subsection{Description of the Hotel des Thermes of Antsirabe}

The Hotel des Thermes is one of the jewel hotels of Antsirabe located in the middle of the city near the station and the thermal cure center. Historically, the King of Morocco Mohamed $\mathrm{V}$ resided for a few years in this hotel.

This three stars hotel has 32 rooms of which 28 ordinary rooms and 3 suites. Each room is equipped with heating system, 1 satellite television and 1 telephone, 1 bathroom containing shower and bath tub, 1 safe and 1 balcony with armchair. All rooms look out on the swimming pool of the hotel.

\section{METHOD}

\subsection{Available Thermal Water and Valorization of Heat Losses}

Assuming that geothermal water has the same physical properties as those of typical surface water, the heat loss $\mathrm{Q}_{\text {loss }}(\mathrm{J})$ can be calculated as

$\mathrm{Q}_{\text {loss }}=\dot{m} \cdot \mathrm{c} .\left(\mathrm{T}_{\mathrm{i}}-\mathrm{T}_{\mathrm{u}}\right)$

where $\dot{m}$ is the pumped thermal water mass flow rate of $\left(\mathrm{kg} . \mathrm{s}^{-1}\right)$, c represents the heat capacity of usual water and is taken equal to $4186\left(\mathrm{~J} \cdot \mathrm{kg}^{-1} \cdot \mathrm{K}^{-1}\right), \mathrm{T}_{i}$ denotes the initial temperature of thermal water outgoing the well $R 1$ or $R 2$, and $T_{u}$ is the extracted thermal water temperature of use in the cure center and is equal 36 $\left({ }^{\circ} \mathrm{C}\right)$.

\subsection{Energy Consumption Assessment}

For hot water production, the energy consumption $\mathrm{Q}_{\text {cons }}(\mathrm{J})$ is estimated in terms of required electric energy and can be computed by:

$\mathrm{Q}_{\text {cons }}=c . \rho \cdot \mathrm{V} \cdot\left(\mathrm{T}_{\mathrm{h}}-\mathrm{T}_{\mathrm{c}}\right)$

where $c$ denotes the heat capacity of usual water $\left(\mathrm{J} \cdot \mathrm{kg}^{-1} \cdot \mathrm{K}^{-1}\right), \rho$ and $\mathrm{V}$ are respectively the density $\left(\mathrm{kg} \cdot \mathrm{m}^{-3}\right)$ and the volume $\left(\mathrm{m}^{3}\right)$ of the water to warm from the cold temperature $T_{C}(K)$ to the desired hot temperature $T_{h}(K)$.

Besides, the amount of energy consumed per day by any electrical appliance $\mathrm{Q}_{a p p}\left(\mathrm{~kJ}\right.$ day $\left.{ }^{-1}\right)$ used in the thermal center is calculated by: 


$$
\mathrm{Q}_{a p p}=\text { P.t. } 3600
$$

where $\mathrm{P}$ denotes the power $(\mathrm{kW})$ and $\mathrm{t}$ is the number of usage hours per day (h.day ${ }^{-1}$ ) of the appliance.

Moreover, the amount of energy consumed for pumping a unit volume of thermal water $\mathrm{Q}_{\text {pump }}\left(\mathrm{kJ} . \mathrm{m}^{-3}\right)$ can be computed by:

$\mathrm{Q}_{\text {pump }}=\frac{\mathrm{P}}{d}$

in which $d\left(\mathrm{~m}^{3} \cdot \mathrm{s}^{-1}\right)$ is the volumetric flow rate of the thermal water and $\mathrm{P}$ has the same nomenclature as in Eq. (3).

\subsection{Recovery System of Energy Excess from Thermal Cure Center to Hotel des Thermes for Domestic Hot Water Production}

The minimum temperature required for the supply of domestic hot water is $55\left({ }^{\circ} \mathrm{C}\right)$ while the temperature of the collected thermal water at the well $\mathrm{R} 2$ is $52\left({ }^{\circ} \mathrm{C}\right)$. Accordingly, the considered heat excess recovery system is not capable of supplying the entirety of the hotel's energy needs for the production of its domestic hot water. However, this recovery system can be used for preheating the hotel's sanitary water in order that only a limited amount of supplement electrical energy would be consumed for adjusting the temperature of domestic hot water to the desired value. Figure $\mathbf{3}$ schematizes the sketch of the studied energy excess recovery system, which includes plate heat exchanger and insulated 300-meter-long piping.

\subsection{Optimal Surface of the Plate Heat Exchanger}

The effectiveness-NTU method [8] was used for determining the optimal surface of the plate heat exchanger. Indeed, the effectiveness of a countercurrent flow heat exchanger is given by:

$\varepsilon=\frac{1-\mathrm{e}^{[-(1-\mathrm{R}) \cdot \mathrm{NTU}]}}{1-\mathrm{R} \cdot \mathrm{e}^{[-(1-\mathrm{R}) \cdot \mathrm{NTU}]}}$

where NTU is the number of transfer units (-) that is defined as:

$$
\mathrm{NTU}=\frac{\mathrm{K} \cdot \mathrm{S}}{\min \left[\left(\dot{\mathrm{m}}_{\mathrm{h}} \cdot \mathrm{c}_{\mathrm{h}}\right),\left(\dot{\mathrm{m}}_{\mathrm{c}} \cdot \mathrm{c}_{\mathrm{c}}\right)\right]}
$$

and $R$ denotes the heat capacity ratio (-) which is computed with:

$$
\mathrm{R}=\frac{\min \left[\left(\dot{\mathrm{m}}_{\mathrm{h}} \cdot \mathrm{c}_{\mathrm{h}}\right),\left(\dot{\mathrm{m}}_{\mathrm{c}} \cdot \mathrm{c}_{\mathrm{c}}\right)\right]}{\max \left[\left(\dot{\mathrm{m}}_{\mathrm{h}} \cdot \mathrm{c}_{\mathrm{h}}\right),\left(\dot{\mathrm{m}}_{\mathrm{c}} \cdot \mathrm{c}_{\mathrm{c}}\right)\right]}
$$

in which $\mathrm{c}_{h}$ and $\mathrm{C}_{\mathrm{c}}$ represent the specific heats of the hot and cold fluids respectively $\left(\mathrm{J} \cdot \mathrm{kg}^{-1} \cdot \mathrm{K}^{-1}\right)$

While being defined as the ratio between the actual heat transfer rate and the maximum possible heat transfer rate, the effectiveness of the heat exchanger can also be calculated with:

$$
\varepsilon=\frac{\mathrm{T}_{\mathrm{hi}}-\mathrm{T}_{\mathrm{ho}}}{\mathrm{T}_{\mathrm{hi}}-\mathrm{T}_{\mathrm{ci}}}
$$

Besides, the actual heat transfer rate can be computed with the following thermal balance equation:

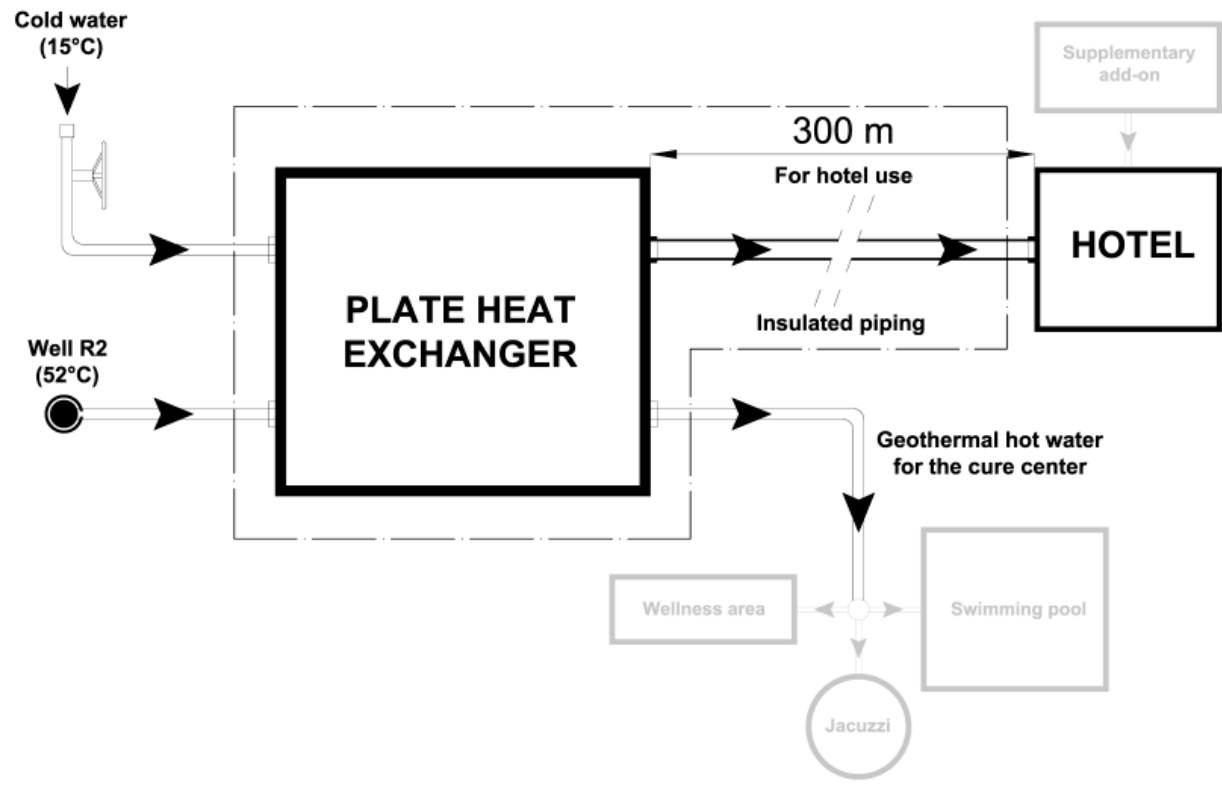

Figure 3: Simplified sketch of the recovery system of energy excess. 


$$
\mathrm{q}=\dot{\mathrm{m}}_{\mathrm{h}} \cdot \mathrm{c}_{\mathrm{h}} \cdot\left(\mathrm{T}_{\mathrm{hi}}-\mathrm{T}_{\mathrm{ho}}\right)=\dot{\mathrm{m}}_{\mathrm{c}} \cdot \mathrm{c}_{\mathrm{c}} \cdot\left(\mathrm{T}_{\mathrm{co}}-\mathrm{T}_{\mathrm{ci}}\right)
$$

While assuming as known the global heat exchange coefficient $\mathrm{K}$ and the exchange area a of each plate of the heat exchanger, the mass flow rates $\left(\dot{\mathrm{m}}_{\mathrm{h}}\right.$ and $\left.\dot{\mathrm{m}}_{\mathrm{c}}\right)$, the specific heats $\left(c_{h}\right.$ and $\left.c_{c}\right)$ as well as the inlet temperatures $\left(T_{h i}\right.$ and $\left.T_{c i}\right)$ of the hot and cold fluids; here is the procedure for calculating the optimal exchange area of the plate heat exchanger as well as the number of plates:

a) Set a small initial guess for the effectiveness $\varepsilon$ (for example: 60 (\%)),

b) Compute the heat capacity ratio $\mathrm{R}$ by using $\mathrm{Eq}$. (7),

c) Evaluate the NTU by use of Eq. (5),

d) Deduce from Eq. (6) the value of the total exchange area $S$ of the plate heat exchanger,

e) Divide $\mathrm{S}$ by the elementary plate area a and add 2 to the rounded so-obtained number in order to get the number of plates that should constitute the heat exchanger entirety (including the two external plates),

f) The outlet temperatures of the hot and cold fluids can be calculated by using Eqs. (8) and (9) successively,

g) Validate results by verifying that the hot fluid outlet temperature suits the need of the thermal swimming pool (superior to $36\left({ }^{\circ} \mathrm{C}\right)$ ) and the cold fluid outlet temperature is superior to $46\left({ }^{\circ} \mathrm{C}\right)$. Otherwise, increment the value of the effectiveness $\varepsilon$ and resume from step $b$ )

h) By plotting together the number of necessary plates and the outlet temperature of the cold fluid $v s$. the heat exchanger effectiveness $\varepsilon$, the optimal value of $\varepsilon$ can be determined graphically. Then, the corresponding value of the optimal exchange area of the plate heat exchanger as already computed in step d) can be adopted.

\subsection{Economic Evaluation of Geothermal and Solar Plants}

\subsubsection{Return on Investment Time}

The investment costs of studied systems have been estimated taking into account the installation and workforce costs.
The economic evaluation of these two systems is based on return on investment (ROI). The ROI indicates the time project profitability which is determined graphically representing the net present value (NPV) [9] of each studied system that was evaluated considering an annual discount rate i. The NPV values can be determined by:

$$
\mathrm{NPV}=\sum_{\mathrm{k}=1}^{\mathrm{n}} \mathrm{S}_{\mathrm{k}}(1+\mathrm{i})^{-\mathrm{k}}
$$

where $S_{k}$ represents the economic saving per year $(€ /$ year), i denotes the considered annual discount rate (\%) that is used to reduce the $\mathrm{ROI}$ and $\mathrm{n}$ designates the time horizon of the investment (year).

\subsubsection{Energy Saving}

For any RET of choice, the energy saving $\mathrm{Q}_{\text {sav }}(\mathrm{kJ})$ is computed by:

$\mathrm{Q}_{\text {sav }}=\mathrm{Q}_{\text {tot }}-\mathrm{Q}_{e}$

where $\mathrm{Q}_{\text {tot }}(\mathrm{kJ})$ denotes the total energy need of the hotel and $\mathrm{Q}_{e}(\mathrm{~kJ})$ is the electric energy need for adjusting the temperature to the desired value.

\section{RESULTS AND DISCUSSION}

\subsection{Availability of Thermal Energy and Collected Hot Water Management}

The thermal cure center hosted 120 to 250 patients a day in 2010 with a total of hot water of $87,500\left(\mathrm{~m}^{3}\right)$ a year, assuming that each patient uses $1\left(\mathrm{~m}^{3}\right)$ averagely.

The thermal water is used for 80 years and the artificial lake of Ranomafana was created to keep up the pressure near the station. Both wells are equipped with electric compressor engines having a capacity of 1.9 (kW).

It should be noted that the thermal water flow rate at the well R1 is $20\left(\mathrm{~m}^{3} \cdot \mathrm{h}^{-1}\right)$ and that of the well $R 2$ is 28 $\left(\mathrm{m}^{3} \cdot \mathrm{h}^{-1}\right)$. Then, using Eq. (4), the amounts of energy consumed by R1 and R2 for unit volume of thermal water are respectively of 342 and $245\left(\mathrm{~kJ} \cdot \mathrm{m}^{-3}\right)$.

While the thermal center working during 350 days a year and the well R1 operating 8 hours a day, and by using Eq. (3), the energy consumed to meet the center's hot water demand of $20\left(\mathrm{~m}^{3} \cdot \mathrm{h}^{-1}\right)$ is about 54,720 (kJ.day $^{-1}$ ), that is $19,152,000$ (kJ.year ${ }^{-1}$ ). Similarly, while the well R2 operating for 7 hours at 
night and 3 hours in daytime, Eq. (3) yields daily energy consumption of $68,400\left(\mathrm{~kJ}_{\text {day }}{ }^{-1}\right)$, that is 23,940,000 (kJ.year $\left.{ }^{-1}\right)$.

Accordingly, the well R1 generates hot water at the temperature of $47\left({ }^{\circ} \mathrm{C}\right)$ with a volumetric flow rate of $160\left(\mathrm{~m}^{3} \cdot\right.$ day $\left.^{-1}\right)$ and by using Eq. (1), the well R1 presents a recoverable heat of $7,367,364\left(\mathrm{~kJ}_{\text {.day }}{ }^{-1}\right)$, whereas the recoverable heat at the well $\mathrm{R} 2$ is about $18,753,260\left(\mathrm{~kJ} \mathrm{day}^{-1}\right)$ as it produces $52\left({ }^{\circ} \mathrm{C}\right)$ of thermal water with a volumetric flow rate of $280\left(\mathrm{~m}^{3} \cdot\right.$ day $\left.^{-1}\right)$.

Henceforth, the plate heat exchanger which is the main equipment for the geothermal excess heat recovery proposed in this project is assumed to be installed just at the well R2 outlet.

\subsection{Energy Requirement of the Thermal Center}

The thermal balance is established considering the energy consumption for the thermal hot water output. The thermal cure center only uses electricity. When there was no data available, a number of values were estimated while basing this estimate on the center's staff recommendations according to their experience.

Indeed, medical practice is the main thermal water consumption of the center. For that purpose, this balneotherapy station has bathtubs for the thermal baths, system watering for underwater massage and pressurized shower system. The consumptions of thermal water for these practices are estimated as follows: the thermal baths require $0.5\left(\mathrm{~m}^{3}\right)$ per bath, underwater massage necessitates $0.5\left(\mathrm{~m}^{3}\right)$ per person and pressurized shower needs $0.5\left(\mathrm{~m}^{3}\right)$ per person.

While using Eq. (3) and taking into account the capacities and the number of usage hours per day ( 8 hours for R1 and 10 hours for R2) of the compressor engines, the whole consumed energy is about 43,092,000 (kJ.year ${ }^{-1}$ ).

For massage and pressurized showers, the center uses three pumps whose power is $1.2(\mathrm{~kW})$ for each. The usage time is assumed 6 hours 30 minutes a day. Then, by use of Eq. (3), the electricity consumption for these activities is about 29,484,000 (kJ.year ${ }^{-1}$ ).

Power consumption is also due to the use of office equipment ( 3 computers whose power being assumed equal to $0.2(\mathrm{~kW})$ for each) as well as human functional rehabilitation devices (one treadmill of $1(\mathrm{~kW})$ and one stationary bike engine of $0.4(\mathrm{~kW}))$. The total consumed power due to the use of these two devices during 8 hours and 6 hours respectively is about $16,632,000$ $\left(\mathrm{kJ}^{\text {year }}{ }^{-1}\right)$.

\subsection{The Hotel Hot Water Needs}

The hot water output of the hotel is provided by electric water-heaters. The capacities of water-heaters are given in Table 1.

Table 1: Electric Water-Heaters Distribution in the Hotel

\begin{tabular}{|c|c|c|c|}
\hline Room types & Number & Capacity (liter) & Power (kW) \\
\hline \hline Ordinary room & 28 & 150 & 1.65 \\
\hline Suite & 3 & 250 & 3.00 \\
\hline
\end{tabular}

The ordinary rooms can host a maximum of 2 persons while a suite can accommodate at most 4 persons. The domestic hot water demand shall be supplied at $55\left({ }^{\circ} \mathrm{C}\right)$ from a cold water at $15\left({ }^{\circ} \mathrm{C}\right)$, that means a temperature rise of $40\left({ }^{\circ} \mathrm{C}\right)$. Using Eq. (2), that corresponds to an energy consumption of 167,436 $\left(\mathrm{kJ} \cdot \mathrm{m}^{-3}\right)$.

For assessing the hotel hot water needs, the daily hot water demand of each customer of the hotel was assumed equal to 80 liters. While this hotel establishment can welcome in total 72 people, its daily hot water demand is about $5.76\left(\mathrm{~m}^{3}\right)$ and using Eq. (2), it implies a daily energy consumption of 964,440 (kJ).

This hotel takes two weeks of annual time off, that means 350 days of activity, that is $337,557,600$ $\left(\mathrm{kJ}\right.$ year ${ }^{-1}$ ) of annual energy need for meeting its customers requirement of domestic hot water.

The studied hotel's hot water needs was estimated online with sizing Solo Code, that is available on Tecsol web site [10], and that makes use of computing algorithms developed by the CSTB (Centre Scientifique et Technique du Bâtiment). Precisely, to run such online calculations, the following inputs were entered as the sector of activity or the category of use of the establishment was defined as hotel business: the category of the hotel, the geographic zone, the number of rooms (a suite being considered as two rooms in our investigation).

While assuming that the hotel has 85 (\%) of occupancy rate, domestic hot water consumption is 4,896 liters a day. Thus, the hotel annual energy need computed online with Solo Code, is about $267,418,800$ $\left(\mathrm{kJ}\right.$ year $\left.{ }^{-1}\right)$. This value will be taken as reference for ulterior calculations. 


\subsection{Coverage of Solar Water-Heaters for the Hotel Hot Water Needs}

The purpose of this section is to estimate the solar gain using solar water-heaters to cover the hotel hot water needs.

Based on data provided by the hotel, Figure $\mathbf{4}$ shows the hotel hot water consumption and its occupancy rate throughout a typical year considering the hot water requirement of 80 (liters/day/person). The occupancy rate has been defined by considering the average ratio between the number of rented rooms and that of available rooms throughout the month. This ratio varies throughout the year and the hotel occupancy rate peaks between July and September as guests are numerous during this vacation period. The annual average occupancy rate is 55.75 (\%) with a maximum of hot water need of 5,760 liters a day (corresponding to $100(\%)$ of occupancy rate).

Due to the richness in biodiversity and the insular nature of Madagascar, this island has considerable tourism potential. In this case, we can consider a higher occupancy rate for the future. Thus, an occupancy rate of 85 (\%) is assumed for our calculation.

The types of SWHs available on the local market have an area of $8.25\left(\mathrm{~m}^{2}\right)$ with a 500 liter tank. For the hotel's hot water needs calculation, we assume that each unit of this SWH type can provide 1,000 liters of hot water. Besides, an occupancy rate of 85 (\%) of the hotel was assumed as previously mentioned, that is, 62 occupants, each of whom needs 80 liters per day, the hotel has to produce 4,896 liters of hot water. Accordingly, it is necessary to install 5 units of solar water-heater system for producing 5,000 liters of hot water. Thus, the total area of SWHs is $41.25\left(\mathrm{~m}^{2}\right)$. Then, the following parameter values were inputted in Solo Code [10], namely: the abovementioned SWH area, $40\left(^{\circ}\right)$ as roof slope, $14.51\left(^{\circ}\right)$ as orientation with respect to North, thermal conductive coefficient of SWH (coefficient $\mathrm{K}$ ) equal to $1.12\left(\mathrm{~W} \cdot \mathrm{m}^{-2} \cdot \mathrm{K}^{-1}\right)$, optical yield (coefficient $B$ ) equal to 0.781 , storage being located outdoor, desired value of hot water temperature equal to $55\left({ }^{\circ} \mathrm{C}\right)$, storage volume equal to 2,500 liters, cooling constant equal to 0.2278 (Wh.day ${ }^{-1} \cdot \mathrm{L}^{-1} \cdot{ }^{\circ} \mathrm{C}^{-1}$ ) and the installation type qualified as forced flow without heat exchanger. It follows from Solo Code calculation result that SWHs provide $146,779,200 \quad\left(\mathrm{~kJ}\right.$ year $\left.{ }^{-1}\right)$ that represents $54.9(\%)$ of the coverage rate of the hotel annual energy need.

\subsection{Optimizing of the Plate Heat Exchanger Surface}

While assuming that geothermal water has almost the same physical properties as those of typical surface water, the mass flow rate of the hot water $\dot{\mathrm{m}}_{\mathrm{h}}$ is that at the well R2 outlet where the heat exchanger is supposed to be installed, that is, $9\left(\mathrm{~kg} . \mathrm{s}^{-1}\right)$. Besides, a value of $0.55\left(\mathrm{~kg}^{-1} \mathrm{~s}^{-1}\right)$ was assigned to the cold water mass flow rate $\dot{\mathrm{m}}_{\mathrm{c}}$, which enables to fill all the hotel's heaters as well as its 5,000 liters storage balloon in the meantime as the cure center swimming pool is filled up at night.

As the maximum fluid flow rate $\dot{\mathrm{m}}_{\mathrm{h}}$ ranges between 20 and $70\left(\mathrm{~m}^{3} \cdot \mathrm{h}^{-1}\right)$, a type PW12 plate heat exchanger, manufacturer by CIAT company [11] and characterized

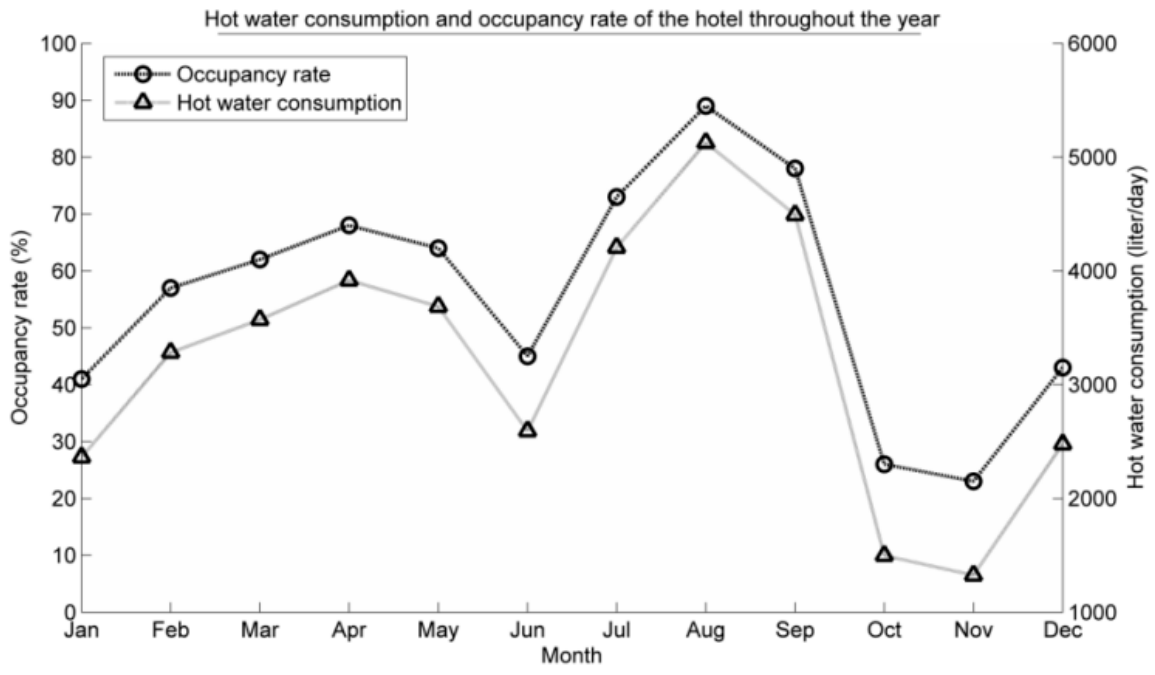

Figure 4: Hot water consumption and occupancy rate of the hotel throughout the year. 


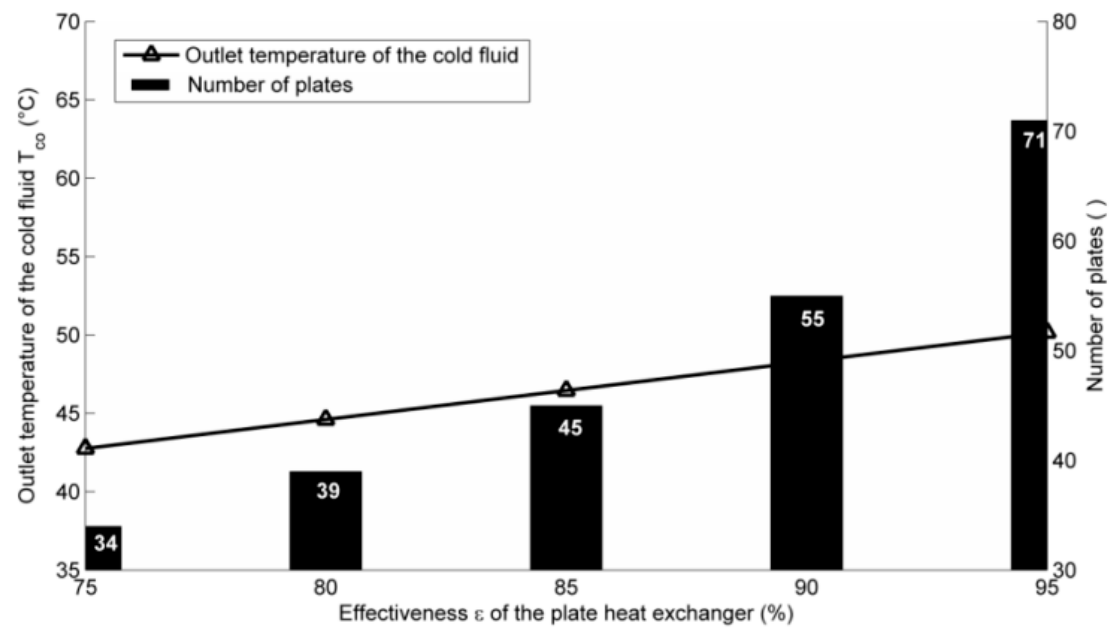

Figure 5: Variations of the cold fluid outlet temperature and the number of plates in terms of the plate heat exchanger effectiveness $\varepsilon$.

by an eligible maximum exchange area of $14.4\left(\mathrm{~m}^{2}\right)$ and a global heat exchange coefficient of 3,200 $\left(\mathrm{W} \cdot \mathrm{m}^{-2} \cdot \mathrm{K}^{-1}\right)$ as well as an elementary plate area of 0.12 $\left(\mathrm{m}^{2}\right)$, was chosen to be used in this project.

It can be seen from Figure 5 that the cold fluid outlet temperature $T_{c o}$ increases along with the heat exchanger effectiveness $\varepsilon$ linearly. That result is obvious as the elimination of the hot fluid outlet temperature $T_{\text {ho }}$ from linear Eqs. (8) and (9) yields a linear relationship between the cold fluid outlet temperature $T_{c o}$ and the heat exchanger effectiveness $\varepsilon$. Besides, the number of plates also increases with $\varepsilon$. However, the plates' number doubles as $\varepsilon$ varies from $75(\%)$ to $95(\%)$. Hence, the middle of this range, that is $85(\%)$, sounds to be the optimal value of $\varepsilon$ as it allows supplying the hotel with some hot water with a temperature nearing $45\left({ }^{\circ} \mathrm{C}\right)$. Subsequently, it is necessary to mount 45 plates on this heat exchanger. The aforementioned number of plates corresponds to a total exchange area value of $5.14\left(\mathrm{~m}^{2}\right)$ which is inferior to the admissible maximum exchange area for this plate heat exchanger type.

Moreover, while using this value of $\varepsilon$, the hot fluid outlet temperature $T_{\text {ho }}$ computed from Eq. (8) was equal to $50.06\left({ }^{\circ} \mathrm{C}\right)$. This temperature value still fulfills the required one to fill the thermal cure center swimming pool (superior to $36\left({ }^{\circ} \mathrm{C}\right)$ ).

\subsection{Design and Sizing of the Hot Water Transport Piping from the Thermal Cure Center Towards the Hotel}

Figure 6 shows the route which the hot water outgoing the heat exchanger has to follow through a buried piping to get to its destination. A reduction in temperature is likely considering the distance to be traveled $(300(\mathrm{~m}))$, it is necessary to insulate the pipe to limit the temperature decrease as least as possible. For that purpose, cross-linked polyethylene, commonly abbreviated PEX or XLPE, was opted for the piping material because of its cost and of its handiness too. Indeed, PEX possesses a weak specific thermal conductivity close to $0.40\left(\mathrm{~W} \cdot \mathrm{m}^{-1} \cdot \mathrm{K}^{-1}\right)$ with regard to that of copper which is $390\left(\mathrm{~W} \cdot \mathrm{m}^{-1} \cdot \mathrm{K}^{-1}\right)$. Such low thermal conductivity value enables to reduce insulation thickness.

\subsection{Economic Evaluation}

The initial investment costs were calculated considering installation and workforce costs. While assuming that the annual energy need was $267,418,800$ (kJ.year $\left.^{-1}\right)$, and that there was a supplement electrical energy both for the two systems for adjusting the temperature of domestic hot water, the additional costs were evaluated with an electricity pricing of $0.05(€ / \mathrm{kWh})$. For against, the economic profits were defined in terms of annual gain in electricity cost of the two studied systems. The details have been reported in Table 2 both for the geothermal and SWHs systems for hot water output:

As can be observed in Table 2, the initial investment related to the proposed geothermal excess heat recovery system is more expensive than that of SWH system. Nevertheless, the annual supplementary electricity cost related to the geothermal option is three fifth of that of the solar solution. 


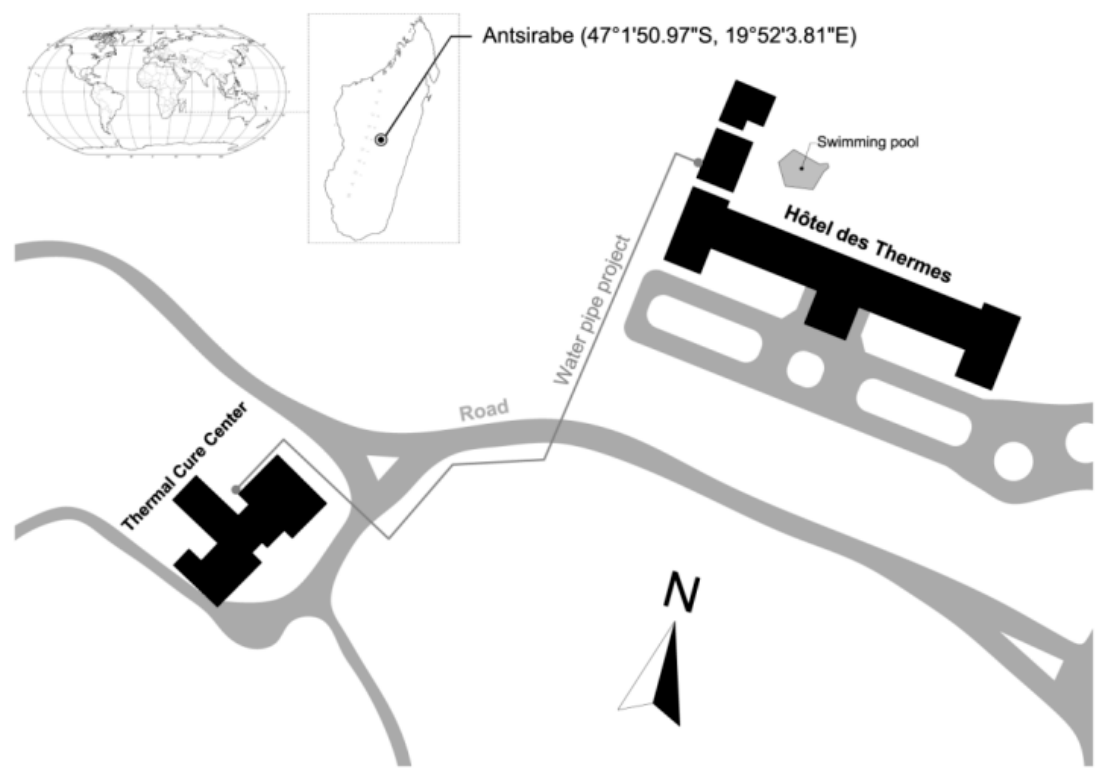

Figure 6: Location of the hot water transport piping project from Thermal Cure Center to Hotel des Thermes.

Table 2: Economic Evaluation of Geothermal Excess Heat Recovery and Solar Energy Plants

\begin{tabular}{|c|c|c|}
\hline Item & Geothermal system & Solar water-heater system \\
\hline Initial investment $(€)$ & 27,844 & 23,981 \\
\hline Additional costs in electricity ( $€ /$ year) & 984 & 1,654 \\
\hline Economic profit (€/year) & 2,684 & 2,014 \\
\hline ROI (year) & 10 & 12 \\
\hline
\end{tabular}

Besides, according to the annual energy need of the hotel of $267,418,800$ (kJ.year $^{-1}$ ) given in section 4.3, and as can be seen in section 4.4 , solar plan can cover $146,779,200$ (kJ.year $^{-1}$ ) that represents 54.9 (\%) of energy savings. For geothermal heat recovery system, the temperature of the provided geothermal hot water is $45\left({ }^{\circ} \mathrm{C}\right)$ while that of hot water needed by the hotel is $55\left({ }^{\circ} \mathrm{C}\right)$, it means a temperature rise of $10\left({ }^{\circ} \mathrm{C}\right)$. By using Eq. (1), the daily electric energy need of the hotel is $204,948(\mathrm{~kJ})$. Assuming that the activities of the hotel stretch on 350 days a year, the annual electric energy need is $71,731,800(\mathrm{~kJ})$ that represents $26.8(\%)$ of electricity needs of the hotel. The remaining required energy is provided by the heat recovery system which represents $73.2(\%)$ of energy savings while using Eq. (11). Thereby, the geothermal system use allows to make energy savings up to 73.2 (\%) compared to 54.9 (\%) for solar plant.

To illustrate and to reduce the $\mathrm{ROI}$ values for both considered green energy technologies (geothermal and solar plants), Eq. (10) calculated their NPV values with discount rates of 2.5, 5 and 7.5 (\%) over 20 years and that were represented in Figure 7.
Net Present Value (NPV) of geothermal and solar water-heater systems over 20 years

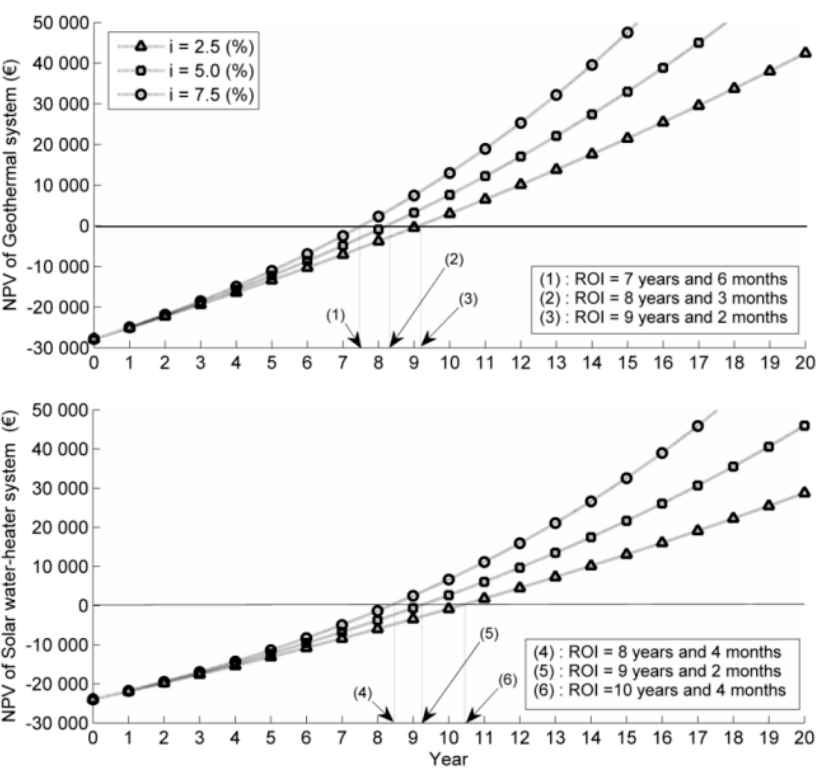

Figure 7: NPV of hybrid geothermal excess heat and hybrid solar water-heater systems over 20 years with discount rates of $2.5,5$ and $7.5(\%)$.

In spite of an initial investment of $27,844(€)$ for the geothermal system greater than 23,981 (€) for solar 
system, the geothermal solution is more profitable in long term and the best $\mathrm{ROI}$ is 7 years and 6 months when it is 8 years and 4 months for SWH system with a discount rate of $7.5(\%)$.

\section{CONCLUSION}

This paper presented an investigation of excess heat recovery system from geothermal sources of thermal cure center to produce domestic hot water to meet the needs of the Hotel des Thermes of Antsirabe, Madagascar. Indeed, excess heats have been noticed outlet of the thermal cure center. The study tends to evaluate the feasibility of available geothermal water and excess heat valorization system using heat exchanger and transport piping between the two establishments.

An assessment of proposed geothermal excess heat recovery system with solar plant was presented for hot water output. Hence, free online Solo code was carried out to estimate the hot water needs of the hotel and to size needed SWHs to cover the hot water requirement of the hotel. The effectiveness NTU method was developed to size the heat exchanger and design the hot water transport piping which should be extended over a length of $300(\mathrm{~m})$ from the thermal cure center towards the hotel. The results also showed that the two systems needed supplement electrical energy to adjust the domestic hot water temperature.

Finally, economic evaluation both of hybrid geothermal excess heat recovery system and hybrid solar energy plant was presented. Furthermore, it was deducted that, in spite of an expensive investment, the hybrid geothermal solution is more interesting than that of hybrid solar plant. Therefore, the geothermal system is the best solution to produce hot water for the hotel with $73.2(\%)$ of electric energy savings compared to solar installation that is only $54.9(\%)$.

\section{ACKNOWLEDGEMENTS}

The authors would like to acknowledge both establishments considered in the present study, namely the Thermal Cure Center and the Hotel des Thermes of Antsirabe, Madagascar for providing data.

\section{APPENDIX: NOMENCLATURE}

c Specific heat $\left(\mathrm{J} \cdot \mathrm{kg}^{-1} \cdot \mathrm{K}^{-1}\right)$

d Volumetric flow rate $\left(\mathrm{m}^{3} \cdot \mathrm{s}^{-1}\right)$
Eq(s). Equation(s)

i $\quad$ Annual discount rate (\%)

JIRAMA Jiro sy Rano Malagasy (power and water provider company in Madagascar)

K Global heat exchange coefficient ( )

$\dot{m} \quad$ Mass flow rate $\left(\mathrm{kg} \cdot \mathrm{s}^{-1}\right)$

NPV Net Present Value $(€)$

NTU Number of Transfer Units ( )

Q Quantity of heat given by hot water (J)

R Heat capacity ratio ( )

RETs Renewable Energy Technologies

ROI Return on Investment, time horizon (year)

R1, R2 Names of the wells drilled at the thermal cure center

S Economic saving (€/year)

SWHs Solar Water-Heaters

$\mathrm{t} \quad$ Usage time $(\mathrm{h})$

$\mathrm{T} \quad$ Temperature $\left({ }^{\circ} \mathrm{K}\right)$

V Volume $\left(\mathrm{m}^{3}\right)$

\section{Greek symbols}

$\varepsilon \quad$ Effectiveness of a counter-current flow ( )

$\rho \quad$ Density $\left(\mathrm{kg} \cdot \mathrm{m}^{-3}\right)$

\section{Subscripts}

c cold

cons Consumption

e Electric

h $\quad$ Hot

i Inlet

loss Loss

- Outlet 


$\begin{array}{ll}\text { pump } & \text { Pumping } \\ \text { sav } & \text { Saving } \\ \text { tot } & \text { Total energy } \\ \text { u } & \text { Operate } \\ \text { w } & \text { Water }\end{array}$

\section{REFERENCES}

[1] International Energy Agency (IEA). Africa Energy Outlook - A focus on energy prospects in Sub-Saharan Africa. 2014. Available from: http://www.iea.org/publications/freepublications/publication/WEO2014_AfricaEnergyOutlook.pdf

[2] ICSHP-UNIDO. World small hydropower development report 2013 - Madagascar. Available from www.smallhydroworld.org

[3] Lund JW, Freeston DH, Boyd TL Direct utilization of geothermal energy 2010 worldwide review. Geothermics 2011; 40: 159-80. http://dx.doi.org/10.1016/j.geothermics.2011.07.004

[4] Calise F, Cipollina A, Dentice d'Accadia M, Piacentino A. A novel renewable polygeneration system for a small
Mediterranean volcanic island for the combined production of energy and water: Dynamic simulation and economic assessment. Appl Energy 2014; 135: 675-93. http://dx.doi.org/10.1016/j.apenergy.2014.03.064

[5] Li T, Zhu J, Xin S, Zhang W. A novel geothermal system combined power generation, gathering heat tracing, heating/domestic hot water and oil recovery in an oilfield. Geothermics 2014; 51: 388-96. http://dx.doi.org/10.1016/j.geothermics.2014.03.009

[6] Jovanovic M, Turanjanin V, Bakic V, Pezo M, Vucicevic B. Sustainability estimation of energy system options that use gas and renewable resources for domestic hot water production. Energy 2011; 36: 2169-75. http://dx.doi.org/10.1016/i.energy.2010.08.042

[7] Andrianaivo L. Caractéristiques générales des systèmes et des régions géothermiques de Madagascar. Madamines 2011; 2: 2220-0681.

[8] Incropera FP, DeWitt DP, Bergman TL, Lavine AS. Fundamentals of heat and mass transfer. 6th ed: John Wiley \& Sons US 2006

[9] Atlason RS, Unnthorsson R. Hot water production improves the energy return on investment of geothermal power plants. Energy 2013; 51: 273-80. http://dx.doi.org/10.1016/j.energy.2013.01.003

[10] Solo sizing. an online hot water calculation tool. Available from: http://www.tecsol.fr/st_uk/calc0-uk.htm

[11] CIAT. Expert in sustainable solution. Available from: http://www.ciat.com/ 